\title{
COMMENTARY
}

\section{Probiotics for severe trauma patients}

\author{
Ger T Rijkers ${ }^{1,2 *}$ \\ See related research by Tan et al., http://ccforum.com/content/15/6/R290
}

\begin{abstract}
Probiotics are live micro-organisms with a health promoting effect. Because of their immunomodulating capacity as well as improvement of gut barrier function, probiotics have the capacity to prevent infectious complications in a variety of clinical settings. Now selected probiotics show potential for improving the clinical outcome of severe trauma patients.
\end{abstract}

The present issue of Critical Care features a publication by Min Tan and colleagues from the Affiliated Hospital of North Sichuan Medical College in China on the use of probiotics in severe traumatic brain injury patients [1]. Critically ill trauma patients have many reasons to develop infectious complications when admitted to the ICU. Trauma causes a massive inflammatory response during which a first phase dominated by pro-inflammatory cytokines is follow by a second phase of immunosuppression in which anti-inflammatory cytokines prevail (immunoparalysis) [2]. Trauma in many cases disrupts the mechanical barriers that prevent micro-organisms from entering the body. Of perhaps even greater impact is the loss of gut barrier integrity, which allows translocation of gut pathogens.

Probiotics have the potential to reduce the infectious complications of these patients because they can limit the mucosal barrier dysfunction and regulate the balance of $\mathrm{CD} 4^{+}$effector $\mathrm{T}$ lymphocytes [3]. Because probiotics are, by definition, live bacteria, there has been hesitation in using them for critically ill patients. By now, many studies have demonstrated the safety of probiotics for a variety of clinical conditions maybe with the exception of acute pancreatitis complicated by multiorgan failure [4-6]. The efficacy of probiotics for critically ill patients is debated because both positive as well as negative results have

\footnotetext{
*Correspondence: g.rijkers@antoniusziekenhuis.nl

'Department of Medical Microbiology and Immunology, St Antonius Hospital

Nieuwegein, PO Box 2500, 3430 EM Nieuwegein, The Netherlands

Full list of author information is available at the end of the article
}

been published. With regard to the prevention of ventilator-associated pneumonia in critically ill patients admitted to the ICU, Morrow and colleagues reported a positive effect [7], while in the study of Barraud and colleagues no effect was found in this respect [8]. Tan and colleagues [1] now present the results of a pilot study on the immunomodulatory as well as clinical effects of a multispecies probiotic preparation in patients with severe brain trauma. Their study is important because it is the first one in this patient category that includes biomarkers of the immune system. Trauma itself is known to cause a depression of the T helper 1 (Th1) cytokines IL-12 p70, and interferon- $\gamma$ [9]. IL-12 is the major Th1 driving cytokine while interferon- $\gamma$ potentiates cellular immunity as well as macrophage function. During the first week no differences in cytokine levels were found between the intervention and control groups, but afterwards, IL-12 $\mathrm{p} 70$, and interferon- $\gamma$ returned to normal faster in the probiotics group. Serum levels of IL-6 and C-reactive protein at days 15 to 21 were lower in the probiotics group.

The probiotics significantly reduced the length of ICU stay (from 10.7 to 6.8 days). They also reduced the frequency of ventilator-associated pneumonia (from 68 to $44 \%$ ) and mortality (from 19 to $11 \%$ ), but with a relatively small group size the study was underpowered to detect differences in these outcome parameters.

Larger, preferably multicenter studies are now needed to confirm these encouraging results. For those studies it will also be important to decide on the choice of probiotics. Not all probiotics are the same - in fact, they are all different. Even between different strains of the same species considerable differences may exist. In the study of Morrow and colleagues [7], Lactobacillus rhamnosus GG (LGG) was used in a dose of $2 \times 10^{9}$ colony forming units (CFU) per day [7]. Barraud and colleagues [8] used a multispecies preparation consisting mainly also of LGG as well as Lactobacillus casei, Lactobacillus acidophilus, and Bifidobacterium bifidum in a total dose of $2 \times 10^{10} \mathrm{CFU}$ per day. The multispecies combination of Tan and colleagues [1] was composed mainly of Bifidobacterium longum as well as Lactobacillus bulgaricus and Streptococcus thermophilus and was used at a total dose of $10^{9} \mathrm{CFU}$ per day. Maintenance (or even 
improvement) of Th1 cytokine-mediated immune functions can be of decisive importance for severe trauma patients. Probiotics selected to fulfill that function may therefore be optimally suited to support the clinical outcome of this category of patients.

\section{Abbreviations}

CFU, colony forming units; IL, interleukin; Th, T helper.

\section{Competing interests}

The author declares that he has no competing interests.

\section{Author details}

'Department of Medical Microbiology and Immunology, St Antonius Hospital Nieuwegein, PO Box 2500, 3430 EM Nieuwegein, The Netherlands. 2Department of Sciences, Roosevelt Academy, Middelburg, The Netherlands.

Published: 29 December 2011

\section{References}

1. Tan M, Zhu JC, Du J, Zhang LM, Yin HH: Effects of probiotics on serum levels of Th1/Th2-cytokine and clinical outcomes in severe traumatic braininjured patients: a prospective randomized pilot study. Crit Care 2011, 15:R290.

2. Hietbrink F, Koenderman L, Rijkers G, Leenen L: Trauma: the role of the innate immune system. World J Emerg Surg 2006, 1:15.

3. Rijkers GT, Bengmark S, Enck P, Haller D, Herz U, Kalliomaki M, Kudo S, LenoirWijnkoop I, Mercenier A, Myllyluoma E, Rabot S, Rafter J, Szajewska H, Watzl B,
Wells J, Wolvers D, Antoine JM: Guidance for substantiating the evidence for beneficial effects of probiotics: current status and recommendations for future research. J Nutr 2010, 140:671S-676S.

4. Besselink MG, van Santvoort HC, Buskens E, Boermeester MA, van Goor H, Timmerman HM, Nieuwenhuijs VB, Bollen TL, van Ramshorst B, Witteman BJ, Rosman C, Ploeg RJ, Brink MA, Schaapherder AF, Dejong CH, Wahab PJ, van Laarhoven CJ, van der Harst E, van Eijck CH, Cuesta MA, Akkermans LM, Gooszen HG; Dutch Acute Pancreatitis Study Group: Probiotic prophylaxis in predicted severe acute pancreatitis: a randomised, double-blind, placebocontrolled trial. Lancet 2008, 371:651-659.

5. Madsen K: Probiotics in critically ill patients. J Clin Gastroenterol 2008, 2(Suppl 3 Pt 1):S116-118.

6. Rayes N, Soeters PB. Probiotics in surgical and critically ill patients. Ann Nutr Metab 2010, 57(Suppl):29-31.

7. Morrow LE, Kollef MH, Casale TB: Probiotic prophylaxis of ventilatorassociated pneumonia: a blinded, randomized, controlled trial. Am J Respir Crit Care Med 2010, 182:1058-1064.

8. Barraud D, Blard C, Hein F, Marçon O, Cravoisy A, Nace L, Alla F, Bollaert PE, Gibot S: Probiotics in the critically ill patient: a double blind, randomized, placebo-controlled trial. Intensive Care Med 2010, 36:1540-1547.

9. Miller AC, Rashid RM, Elamin EM: The "T" in trauma: the helper T-cell response and the role of immunomodulation in trauma and burn patients. J Trauma 2007, 63:1407-1417.

doi:10.1186/cc10589

Cite this article as: Rijkers GT: Probiotics for severe trauma patients. Critical Care 2011, 15:1022. 